\title{
血管内皮細胞を介する好中球遊走における 血小板活性化因子の役割解析
}

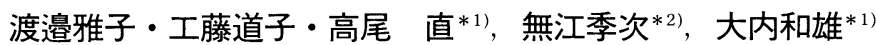

Analysis of roles of platelet activating factor in neutrophil transendothelial migration

In an air pouch type allergic inflammation model in rats, PAF antagonists inhibit neutrophil migration into the pouch fluid although levels of PAF in the pouch fluid are less than the detectable amount. To clarify roles of PAF in neutrophil migration, effects of PAF antagonists (CV-6209, L-652, 731, Y24180) on transendothelial migration of neutrophils were examined in vitro. Histamine and thrombin stimulated $\mathrm{LTB}_{4}$-induced transmigration of neutrophils through the confluent monolayer of human umbilical vein endothelial cells (HUVEC). Treatment with PAF antagonists selectively inhibited the histamine- and thrombin-induced transendothelial migration, suggesting that PAF plays some significant roles in endothelial cell recognition by neutrophils.

Treatment of HUVEC with TNF- $\alpha$ or IL- $1 \beta$ induced neutrophil adherence to HUVEC monolayer and expression of adhesion molecules, such as ICAM-1, ELAM-1 or GMP-140. However, PAF antagonists showed no effect on the cytokineinduced neutrophil adherence to HUVEC nor the expression of these adhesion molecules. Furthermore, histamine- and thrombin-induced neutrophil adherence to HUVEC was inhibited by PAF antagonists without altering the expression of these adhesion molecules.

Transendothelial migration of neutrophils was not inhibited by antibodies to GMP-140 and ELAM1 , but was completely inhibited by an antibody to LFA- $1 \beta$. An antibody to ICAM-1 partially inhibited the transendothelial migration of neutrophils.

These results suggest that PAF produced by HUVEC plays important roles in signaling for neutrophil adherence to endothelial cells without affecting the expression of these adhesion molecules.

*1) Department of Biochemistry, Faculty of Pharmaceutical Sciences, Tohoku University 東北大学薬学部生 化学講座

${ }^{* 2)}$ College of Medical Sciences, Tohoku University 東北 大学医療技術短期大学部

\author{
Masako Watanabe $\cdot$ Michiko Kudoh \\ Sunao Takao*1), Suetsugu Mue ${ }^{* 21}$ \\ Kazuo Ohuchi*1) \\ key words : platelet activating factor, \\ adhesion molecules, endothelial cells
}

好中球浸潤を一つの特徴とするラットのアレル ギー性空気囊型炎症モデルは，あらかじめラット を抗原蛋白質 (ABA-AcBSA) で感作し, 背部皮下 に作成した空気囊(air pouch)内に抗原液を注入 して，アレルギー反応に基づく炎症反応を誘発す るモデルである1).

感作群では, 抗原液注入直後に肥満細胞の脱顆 粒によるヒスタミン放出に基づく一過性の血管透 過性亢進が起こり, その後, 48 時間にかけて pouch 内液中に浸潤する顆粒球数は経時的に増加 する。一方, 無感作ラットの air pouch 内に抗原 液を注入した場合のヒスタミン放出は, 感作群に くらべるときわめてわずかであり2，また，顆粒球 浸潤は炎症誘発後 4 時間までアレルギー群と同様 に上昇するが，その後の浸潤は弱くなる。

アレルギー性炎症の誘発により浸潤する顆粒球 は $90 \%$ 以上が好中球であり，抗原刺激後 4 時間以 降の好中球浸潤は, 血小板活性化因子 (PAF)の特 異的拮抗薬を抗原刺激時に静脈注射あるいは pouch 内に局所投与すると用量依存的に抑制され $る^{3,4)}$.

一方，無感作ラットの air pouch 内に抗原液を 注入して引き起こされる 4 時間後以降の弱い好中 球浸潤は, PAF 拮抗薬の投与によってまったく抑 制されない。

PAF は好中球に対してきわめて強い走化性を 示す物質であるため，ラットのアレルギー性炎症 モデルにおいて PAF が走化性因子として関与し ている可能性について解析した.

その結果, pouch 内液中の PAF 量は, ウサギ 
洗浄血小板を用いたバイオアッセイ法で検出限界 以下であり ${ }^{3)}, \mathrm{PAF}$ の前駆体あるいは代謝物であ る 1yso-PAF レベルも低かっだ” . さらに，多く の炎症性細胞では, PAF は種々の刺激により産生 されても細胞外へはほとんど遊離しないため, ラットのアレルギー性炎症モデルでは PAF が走 化性因子として作用している可能性はきわめて低 いものと思われる。

前述したように, PAF 拮抗薬は, アレルギー性 炎症に抢ける好中球浸潤を抑制する。PAF が走化 性因子として作用していないとすると, PAF 拮抗 薬が PAF に対する好中球の遊走を抑制し，それ によって炎症モデルに拝ける好中球浸潤を抑制す るという考えは成立しなくなる。

そこで，好中球遊走以前の過程，すなわち，好 中球の血管内皮細胞認識(接着)の過程，ならびに 血管内皮細胞層を介する好中球の遊走 (transendothelial migration)の過程における PAF の関 与について，血管内皮細胞の培養系を用いて検討 した。

\section{方 法}

（1）ヒト血管内皮細胞の採取および培養 0.25\% trypsin- $0.01 \%$ EDTA 処理によりヒト 臍帯静脈から血管内皮細胞を採取し，初代は $20 \%$ FBS 添加 199 培地 $(+1 \%$ Amphotericin B 溶 液), 2 代目は $10 \%$ FBS 添加 199 培地 $(+1 \%$ Amphotericin B 溶液, heparin $90 \mu \mathrm{g} / \mathrm{ml}$, ECGS $5 \mu \mathrm{g} / \mathrm{ml}$ ) で培養した。予めコラーゲン(高研, Cellgen, 中性, E'MEM 培地)でコートした transwell (12-well 用, Costar, poresize $3.0 \mu \mathrm{m})$ ， あるい は 24-well マルチディッシュ(Costar)に 2 代目 血管内皮細胞の confluent monolayer を形成させ 実験に用いた。

（2） ラット腹腔好中球の採取と ${ }^{51} \mathrm{Cr}$ 標識

ラットの腹腔に 1 \%カゼイン溶液を注入し (120 $\mathrm{ml} / \mathrm{kg}), 15$ 時間後に腹腔浸潤細胞を回収した. 洗 浄後， $0.25 \%$ BSA (fatty acid-free) を含む 199 培 地に眯濁し, ${ }^{51} \mathrm{Cr}$ 溶液 $\left(\mathrm{NEN}, \mathrm{Na}_{2}{ }^{51} \mathrm{CrO}_{4}\right)$ を添加 して，5\% $\mathrm{CO}_{2}-95 \% \mathrm{O}_{2}$ 存在下 60 分間振盪培養 した. 洗浄後, $0.25 \%$ BSA (fatty acid-free) を含 む 199 培地で $3 \times 10^{6} \mathrm{cells} / 250 \mu \mathrm{l}$ の濃度の細胞浮 遊液を調製した。
（3）血管内皮細胞層に対する好中球接着の測 定(図 1 a)

24-well マルチディッシュに形成させたヒト血 管内皮細胞の confluent monolayer に, ${ }^{51} \mathrm{Cr}$ で 標識したラット腹腔好中球浮遊液 $\left(3 \times 10^{6}\right.$ 個 $/ 250$ $\mu 1)$ を添加し，ただちに2 培濃度の薬物を含む 0.25\% BSA-199 培地 $250 \mu \mathrm{l}$ を添加してょく振り 混ぜ, $5 \% \mathrm{CO}_{2}$ 存在下, $37^{\circ} \mathrm{C}$ で 20 分間静置培養し た。培養終了後, 承冷した 199 培地で洗浄し, 接 着しなかった好中球を洗い出した.ついで, $500 \mu 1$ の $0.1 \mathrm{~N} \mathrm{NaOH}$ を加えて血管内皮細胞と接着好中 球を回収し， $\gamma$ カウンターで放射活性を測定した。

（4）血管内皮細胞層を介寸る好中球遊走の測 定(図 1 b)

予め transwell 下室に各薬物溶液 $1.5 \mathrm{ml}$ を分 注し，血管内皮細胞の confluent monolayer を形 成させた 12-well 用 transwell をセットした。 transwell カップ内 (上室)に ${ }^{51} \mathrm{Cr}$ 標識ラット腹腔 好中球浮遊液 $\left(3 \times 10^{6}\right.$ 個 $\left./ 250 \mu 1\right)$ を添加し，ただち に 2 培濃度の薬物を含む $0.25 \%$ BSA-199 培地 $250 \mu 1$ を添加してよく振り混ぜ, $5 \% \mathrm{CO}_{2}$ 存在下, $37^{\circ} \mathrm{C}$ で 60 分間静置培養した.

培養終了後, 氷冷した 199 培地でカップ内を洗 浄し, 接着しなかった好中球を洗い出した。 カッ プの外液を全量回収し，放射活性を測定して，血 管内皮細胞層を通過した遊走好中球数の指標とし た。

（5）内皮細胞上の接着分子の測定

各種薬物を添加して一定時間後に内皮細胞を回 収し，それぞれの接着分子に対する抗体を用いて 血管内皮細胞表面の接着分子発現をフローサイト メトリーにより解析した。

\section{結 果}

（1）トロンビン，ヒスタミンによる好中球の transendothelial migration の増強と PAF 拮 抗薬による抑制

図 $2 \mathrm{a}, \mathrm{b}$ に示すように, transwell 上室にトロ ンビン $(1 \mathrm{U} / \mathrm{ml})$ を添加した場合, あるいは下室に 走化性因子として $\mathrm{LTB}_{4}\left(3 \times 10^{-8} \mathrm{M}\right)$ を添加した 場合，ともに血管内皮細胞層を通過して下室へ遊 走する好中球数は増加した。 また，上室にトロン ビン，下室に $\mathrm{LTB}_{4}$ を同時に添加すると，下室へ 

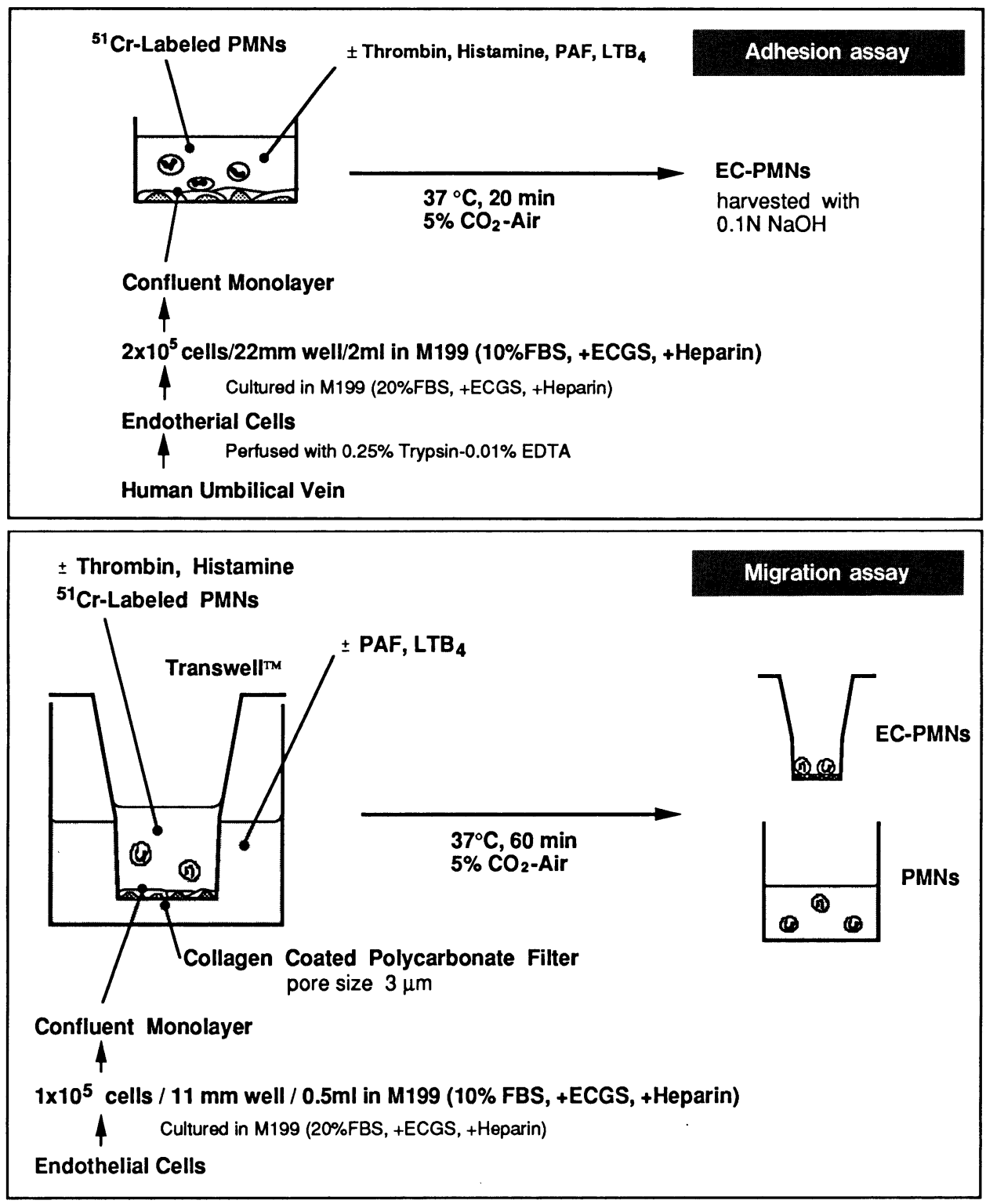

図 1 培養血管内皮細胞への好中球接着と血管内皮細胞層を通過する好中球遊走の実験方法

遊走する好中球数はさらに増加した。このような 系で transwell 上室と下室に PAF 拮抗薬 L-652, $731\left(3 \times 10^{-7} \mathrm{M}\right)$ あるいは $\mathrm{CV}-6209\left(3 \times 10^{-8} \mathrm{M}\right)$ を 添加すると，下室に $\mathrm{LTB}_{4}$ を添加した場合の好中 球遊走は抑制されなかったが, 上室にトロンビン, 下室に $\mathrm{LTB}_{4}$ を同時に添加した場合の好中球遊 走は下室に $\mathrm{LTB}_{4}$ を添加した場合のレベルにま で抑制された。すなわち，上室に添加したトロン ビンの作用は, PAF 拮抗薬によって打ち消される
結果が得られた。

同様の結果は, トロンビンのかわりにヒスタミ ン $\left(1 \times 10^{-5} \mathrm{M}\right)$ を用いた場合にも観察された(data not shown).

（2）血管内皮細胞における接着分子, ICAM1 および ELAM-1 の発現誘導に対する PAF 拮抗薬の作用

好中球浸潤には，炎症局所で産生されるサイト カインによって血管内皮細胞上に誘導される 


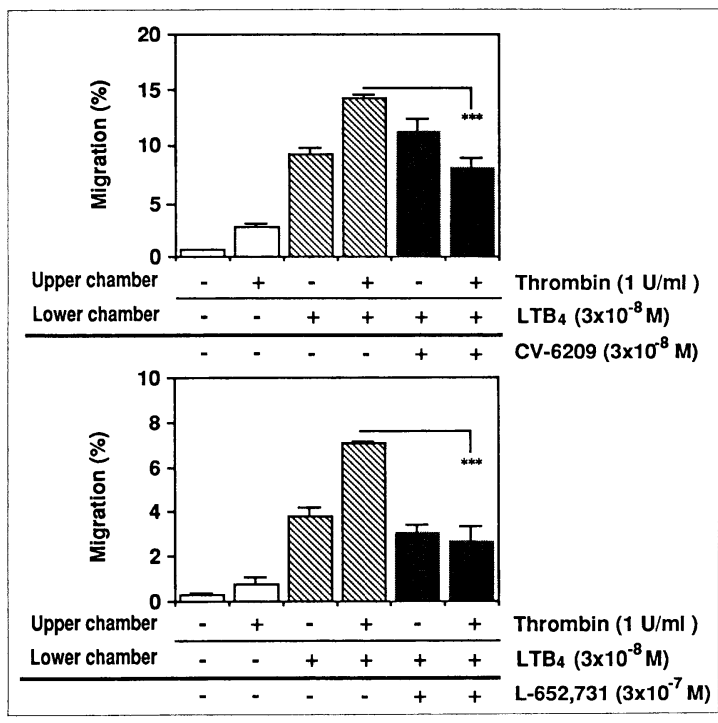

図 2 トロンビンによる好中球の transendothelial migration の増強と PAF 拮抗薬 による抑制

血管内皮細胞の confluent monolayer を形成 させた transwell の上室にトロンビン（1 U/ $\mathrm{ml})$ と ${ }^{51} \mathrm{Cr}$ 標識好中球, 下室に $\mathrm{LTB}_{4}\left(3 \times 10^{-8}\right.$ M)を添加し, $5 \% \mathrm{CO}_{2}$ 存在下, $37^{\circ} \mathrm{Cで} 60$ 分間 静置培養し, 下室に遊走した好中球の割合を測 定した. PAF 拮抗薬 CV-6209 あるいは L-652, 731 は transwell 上室と下室に添加した. *** $\mathrm{P}<0.001$ vs. corresponding control.

ICAM-1 や ELAM-1 が関与する可能性がある. そこで，血管内皮細胞培養系で TNF- $\alpha$ あるいは IL- $\beta$ により発現が誘導される ICAM-1 および ELAM-1 について, これらの発現に対する各種 PAF 拮抗薬の作用を検討した. その結果, TNF- $\alpha$ $(0.1 \mathrm{ng} / \mathrm{ml})$ あるいは IL- $\beta(10 \mathrm{U} / \mathrm{ml})$ を培養系に 添加して 4 時間後の ICAM-1 あるいは ELAM-1 の発現誘導は, 同時に添加したPAF 拮抗薬 $(\mathrm{CV}$ 6209, Y-24180, L-652,731)により，まったく影響 されなかった(図 3 ).

（3）好中球接着に対する血管内皮細胞上の ICAM-1, ELAM-1 発現の影響と PAF 拮抗薬 の作用

血管内皮細胞を $\mathrm{IL}-1 \beta(30 \mathrm{U} / \mathrm{ml})$ あるいは $\mathrm{TNF}-$ $\alpha(0.1 \mathrm{ng} / \mathrm{mb})$ で, 予め 4 時間培養し, ICAM-1 および ELAM-1 を発現させた後, ヒスタミン $\left(10^{-5} \mathrm{M}\right)$ あるいはトロンビン $(1 \mathrm{U} / \mathrm{ml})$ 存在下で ${ }^{51} \mathrm{Cr}$ 標識好中球と 20 分間培養した。また, ${ }^{51} \mathrm{Cr}$
標識好中球と培養する間, PAF 拮抗薬 Y-24180 $\left(1 \times 10^{-8} \mathrm{M}\right)$ を共存させ, 好中球の血管内皮細胞へ の接着に対する PAF 拮抗薬の作用について検討 した(図 4 ).

その結果, IL- $1 \beta$ あるいは TNF- $\alpha$ で前処理す ると，ヒスタミンやトロンビンで刺激をしなくて も好中球の接着は有意に元進した。また，ヒス夕 ミン刺激, あるいはトロンビン刺激による好中球 の接着六進は，血管内皮細胞を IL-1 $\beta$ あるいは TNF- $\alpha$ で前処理しておくとさらに六進した。こ のような系で PAF 拮抗薬 Y-24180を添加する と, IL-1 $\beta$ あるいは TNF- $\alpha$ で前処理した場合も しない場合も，ヒスタミンあるいはトロンビンに よる接着六進のみが抑制された。IL- $1 \beta$ あるいは $\mathrm{TNF}-\alpha$ で前処理した後, ヒスタミンあるいはト ロンビンで刺激をしない場合の好中球接着え進は PAF 拮抗薬ではまったく抑制されなかった。

(4) ヒスタミン，トロンビンによる血管内皮 細胞上の GMP-140 の誘導に対する PAF 拮抗 薬の作用

血管内皮細胞をヒスタミン $\left(1 \times 10^{-5} \mathrm{M}\right)$ あるい はトロンビン $(1 \mathrm{U} / \mathrm{ml})$ 存在下で培養すると, 20 分 以内に内皮細胞上に GMP-140 が発現される。こ のような系でヒスタミンあるいはトロンビンとと もに PAF 怙抗薬を添加し, 20 分後の GMP-140 発現に対する作用を調べたところ，CV-6209(3× $\left.10^{-8} \mathrm{M}\right), \mathrm{Y}-24180\left(1 \times 10^{-8} \mathrm{M}\right)$ あるいは L-652,731 $\left(3 \times 10^{-8} \mathrm{M}\right)$ を添加しても GMP-140 の発現誘導 はまったく抑制されなかった(図 5 ).

(5) 好中球の transendothelial migration $に$ 対する接着分子抗体の作用

Transwell 上室にトロンビン $(1 \mathrm{U} / \mathrm{ml})$ ，下室に 走化性因子として $\mathrm{LTB}_{4}\left(3 \times 10^{-8} \mathrm{M}\right)$ を添加して, 60 分間培養したときの血管内皮細胞層を通過す る好中球遊走は, 上室に抗七ト GMP-140 抗体 (WGA-1，1：300，宝酒造）を添加してもまったく 抑制されなかった。

一方, 抗七ト ICAM-1 抗体 (BBA4, 1:300, British Bio-technology Ltd.)を上室に添加する と, 約 50\%の抑制が観察され, 抗ラット LFA-1 $\beta$ 抗体 (WT・3, $1: 300$, 生化学工業)を添加した場合 には, 好中球遊走はコントロールのレベル以下に まで抑制された(図6 a). 


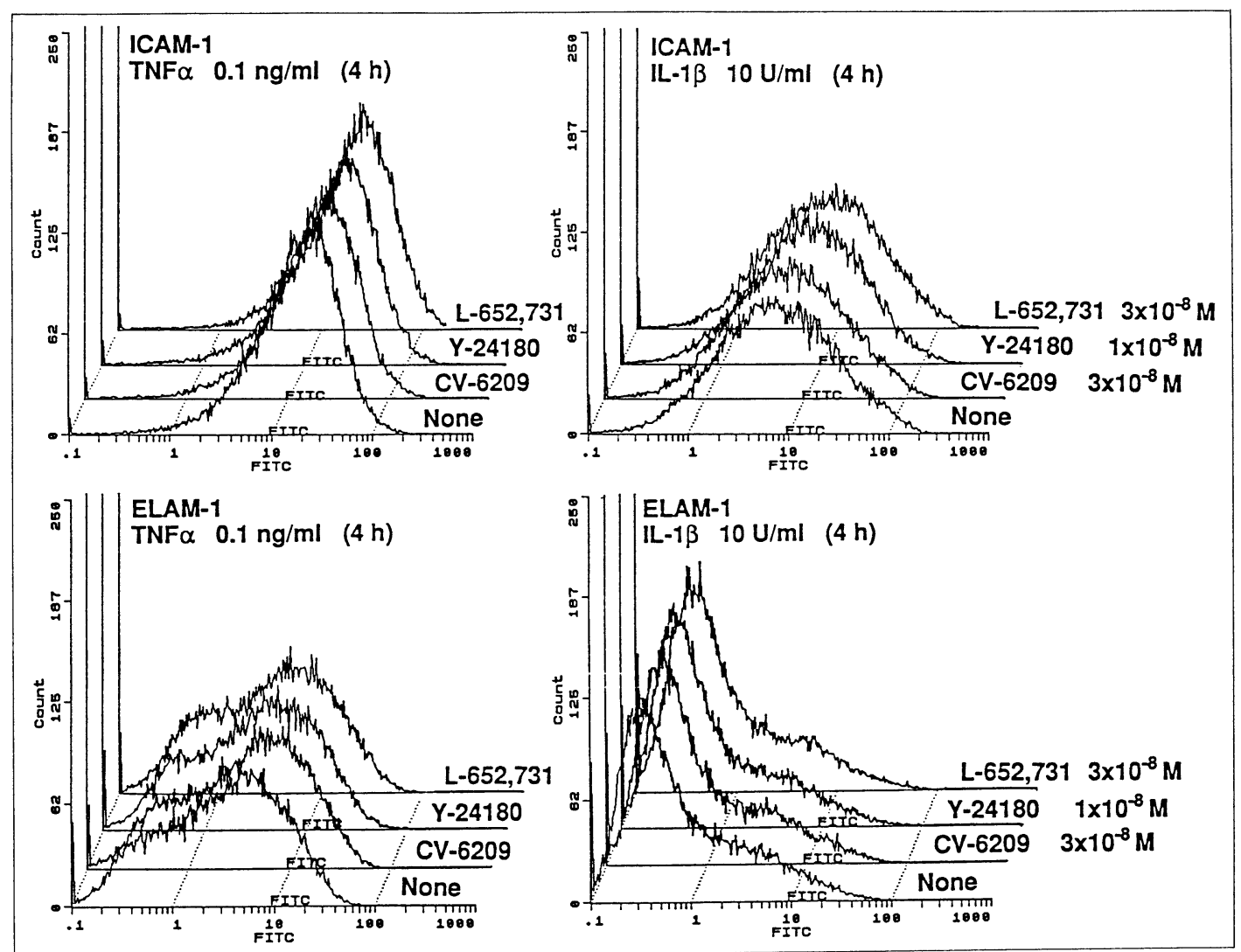

図 3 ICAM-1 および ELAM-1 の発現誘導に対する PAF 怙抗薬の作用

血管内皮細胞を TNF- $\alpha(0.1 \mathrm{ng} / \mathrm{ml})$ あるいは IL-1 $\beta(10 \mathrm{U} / \mathrm{ml})$ を添加した $10 \% \mathrm{FBS}-199$ 培地で 4 時間培養 した。各 PAF 拮抗薬は TNF- $\alpha$ あるいは IL-1 $\beta$ と同時に添加した.

血管内皮細胞を $0.25 \%$ リリプシン $-0.1 \%$ EDTA 溶液で回収した後, 抗ヒト ICAM-1 抗体あるいは抗ヒト ELAM-1 抗体を一次抗体として用い, さらに FITC 標識抗マウス IgG 抗体を二次抗体として用いて免疫染 色を行い, フローサイトメトリー(Coulter 社, Epics Elite)により解析した。

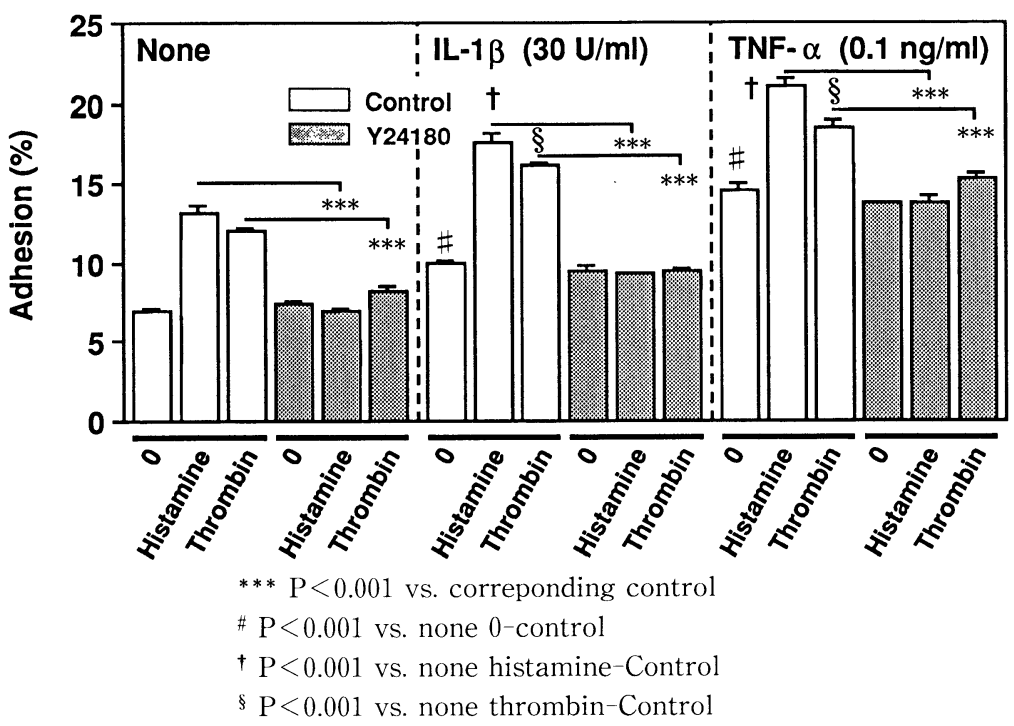

図 4 好中球接着に対する接着分子発 現の影響と PAF 拮抗薬の作用 血管内皮細胞を $\mathrm{TNF}-\alpha(0.1 \mathrm{ng} / \mathrm{ml})$ あるいは IL-1 $\beta(10 \mathrm{U} / \mathrm{ml})$ を添加した $10 \%$ FBS-199 培地で 4 時間培湌し た.

さらに, ヒスタミンあるいはトロン ビンを添加した $0.25 \%$ BSA-199 培地 を好中球と同時に添加し, 20 分間静置 培養した。

接着しなかった好中球を洗い出した 後, $0.1 \mathrm{~N} \mathrm{NaOH}$ で血管内皮細胞と接 着好中球を回収し, 血管内皮細胞に接 着した好中球の割合を測定した. PAF 拮抗薬はヒスタミンあるいはトロンビ ンと同時に添加した。 


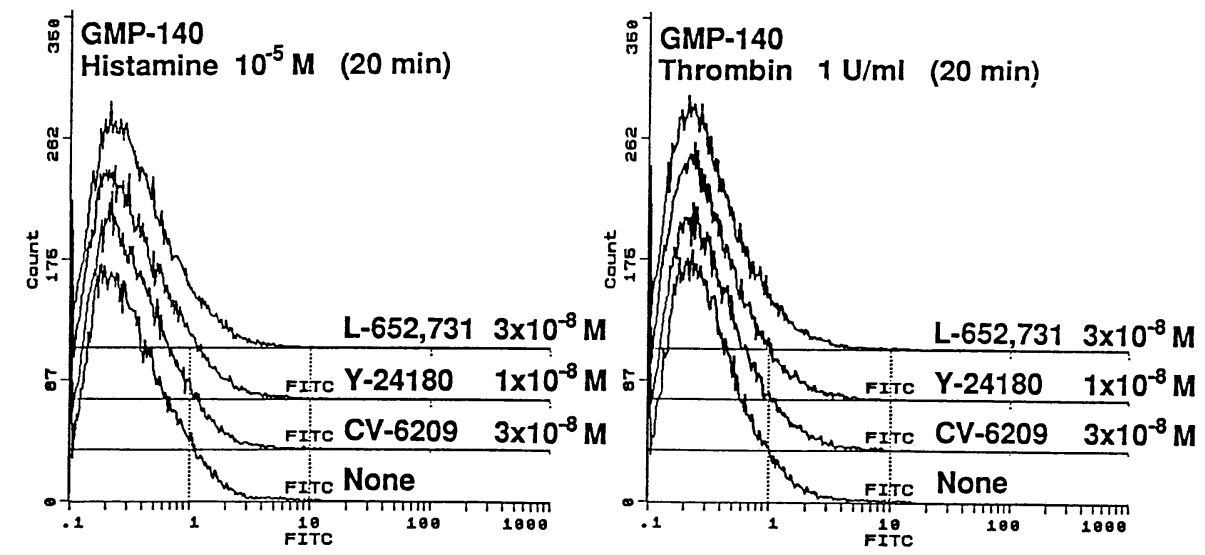

図 5 GMP-140 の発現誘導に対する PAF 拮抗薬の作用

血管内皮細胞に，ヒスタミン $\left(10^{-5} \mathrm{M}\right)$ あるいはトロンビン $(1 \mathrm{U} / \mathrm{ml})$ を含む $0.25 \% \mathrm{BSA}-199$ 培地を添加し, 20 分間培養した。 各 PAF 拮抗薬はヒスタミンあるいはトロンビンと同時に 添加した。血管内皮細胞を $0.25 \%$ トリプシン-0.1\% EDTA 溶液で回収したあと, 抗七ト GMP-140 抗体を一次抗体として, FITC 標識抗マウス IgG 抗体を二次抗体として用いて免 疫染色を行い, フローサイトメトリー(Coulter 社, Epics Elite)により解析した.

また, 培養 60 分後に血管内皮細胞層に接着して いる好中球数は, 抗ヒト GMP-140 抗体 $(1: 300)$ あるいは抗ヒト ICAM-1 抗体 $(1: 300)$ の添加に よる影響は観察されなかった。抗ラット LFA-1 $\beta$ 抗体 (1：300)では, 好中球接着はコントロールの レベルにまで抑制された(図 6 b).

\section{考 察}

トロンビンあるいはヒスタミンは, 血管内皮細 胞に主として細胞結合型のPAFを産生させる が5), トロンビンあるいはヒスタミンによって立 進するヒ卜臍帯静脈血管内皮細胞へのラット腹腔 好中球の接着は，Y-24180, CV-6209 あるいは L652,731 などの PAF 拮抗薬により用量依存的に 抑制されることを報告した6).

好中球は, トロンビンやヒスタミン刺激では PAF を産生せず，また，コラーゲンコートした dish のの好中球接着作用を示さないことから,

PAF 拮抗薬による好中球接着の抑制は, 内皮細胞 が産生する PAF になんらかの形で拮抗した結果 と考えられる。また，ヒスタミン，トロンビン刺 激による血管内皮細胞層を通過する好中球の遊走 も, PAF 拮抗薬により抑制される(図 2)ことか ら，トロンビンあるいはヒスタミン刺激によって 血管内皮細胞が産生する PAF は, 血管内皮細胞
層を介する好中球の遊走を調節している可能性が 強く示唆された。

炎症反応における顆粒球の血管外遊走には，顆 粒球と血管内皮細胞の相互認識機構，すなわちそ れぞれの細胞表面における接着分子の相互作用が 重要であると考えられている。そこで，血管内皮 細胞が産生する PAF と血管内皮細胞が発現する 接着分子が，好中球の接着と遊走にどのように相 互に関連するかについて解析した。

筆者らの実験系では, 血管内皮細胞上の ICAM1 および ELAM-1 の発現量は, 培養時間に関わ らずヒスタミン，トロンビンあるいは PAF に よって変動しなかった. 炎症時の好中球浸潤は, 炎症局所で産生されるサイトカインによって血管 内皮細胞上に誘導される ICAM-1 や ELAM-1 が関与する可能性がある。そこで，TNF- $\alpha$ ある いは IL-1 $\beta$ によって ICAM-1, ELAM-1 を発現 する血管内皮細胞培養系で, これら接着分子の発 現に対する各種 PAF 拮抗薬の作用を検討した.

その結果，いずれのPAF 拮抗薬の影響も観察 されず(図 3 ), 血管内皮細胞が産生する PAF は, 少なくとも ICAM-1 や ELAM-1 の量的変動に は関係のないことが示唆された.

つぎに, ICAM-1, ELAM-1 の接着能に血管内 皮細胞が産生する PAF が関与する可能性につい 


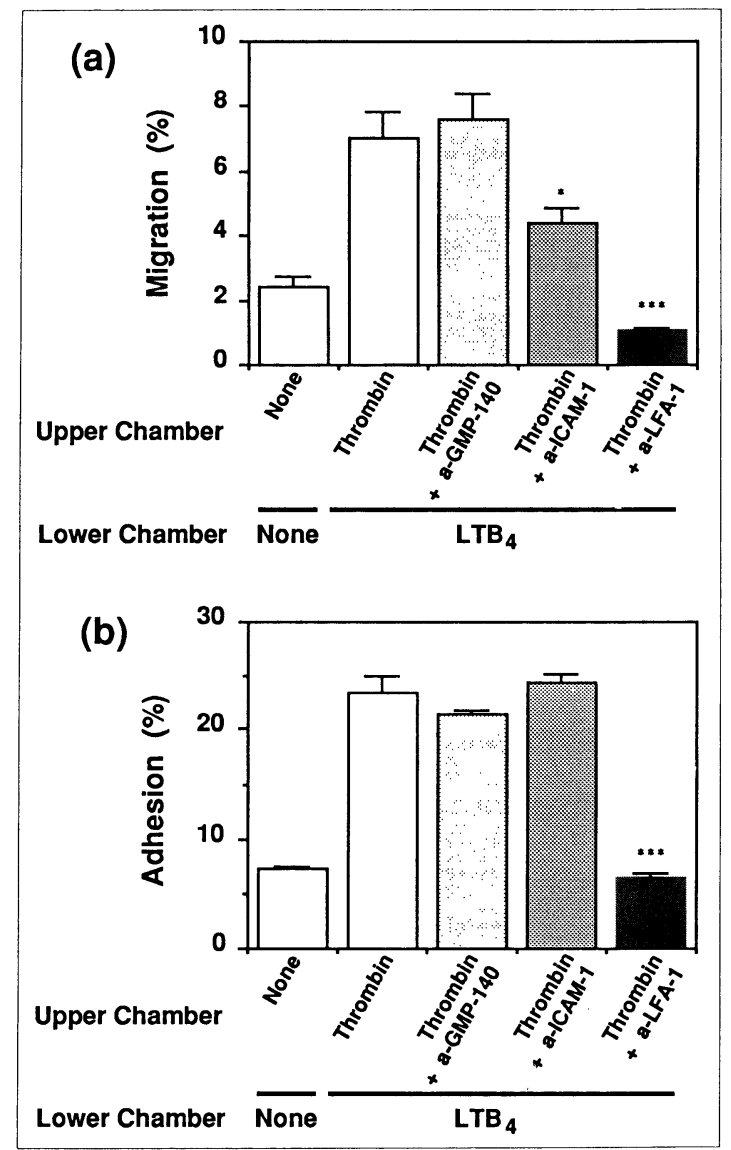

図 6 好中球の transendothelial migration に対す る抗接着分子抗体の作用

Transwell 上室にトロンビン $(1 \mathrm{U} / \mathrm{ml})$ と ${ }^{51} \mathrm{Cr}$ 標識 好中球, 下室に $\mathrm{LTB}_{4}\left(3 \times 10^{-8} \mathrm{M}\right)$ を添加し, 60 分間 静置培養した。下室に遊走した好中球の割合を内皮 細胞層を通過した好中球の指標とした（a). また， transwell フィルターを切り取り放射活性を測定 し，接着好中球の指標とした (b). 各接着分子抗体 (1：300 希釈) は上室にのみ添加した。

${ }^{*} \mathrm{P}<0.05$, ** $\mathrm{P}<0.001$ vs. thrombin control

て検討した，好中球接着の実験系で，血管内皮細 胞を IL-1 $\beta$ や TNF- $\alpha$ で予め 4 時間培養すると, 接着好中球数は有意に増加した(図 4 )。この増加 は ICAM-1 の発現増強や ELAM-1 の発現誘導 によるものと思われる。 IL- $1 \beta$ あるいは TNF- $\alpha$ 前処理後, ヒスタミンやトロンビンを添加すると, 接着好中球数はさらに増加するが, PAF 拮抗薬を ヒスタミンあるいはトロンビンとともに添加する と，ヒスタミンあるいはトロンビンにより充進し た接着のみが抑制された. ICAM-1の発現増強や
ELAM-1 の発現誘導に基づくと思われる接着好 中球数の増加, 寸なわち $\mathrm{IL}-1 \beta$ や $\mathrm{TNF}-\alpha$ 単独 で克進する好中球の接着は抑制されなかった(図 4 ).

したがって，ヒスタミンやトロンビンによる好 中球の接着穴進は, ICAM-1 や ELAM-1 の接着 能を充進した結果ではなく，また，ICAM-1 や ELAM-1 による接着経路と直接的に関連する可 能性はきわめて小さいことが示唆された.

なお，実験に用いたラットの腹腔好中球は， ICAM-1 に対するリガンドである LFA-1 をすで に発現しており，今回の実験条件下では，ヒス夕 ミン，トロンビン， $\mathrm{LTB}_{4}$ あるいは $\mathrm{PAF}$ による 量的変動は観察されなかった(data not shown).

LFA-1 に関しては, 種々の刺激により活性型に かわると考えられているが，ヒト臍带静脈血管内 皮細胞とラット腹腔好中球の組み合わせでは, 添 加した PAF はヒスタミンやトロンビンほど強い 接着六進を示さなかった ${ }^{6)}$.この理由については, 血小板凝集で観察されるように, 動物の種によっ て応答する PAF の分子種が異なるため, LFA-1 の活性型への変換が行われず，接着が六進しな かったか, あるいは, PAF は遊離型ではなく細胞 結合型として存在するときに接着六進に関与する ためであることなどが考えられるが，詳細は不明 である。

また，好中球の PAF 受容体刺激による LFA1 の活性型変換が，血管内皮細胞への好中球接着 と遊走に必要な条件であるかについては現在検討 中である.

ところで，培養血管内皮細胞ではヒスタミンあ るいはトロンビン刺激によりリモデリング経路に より一過性に PAF が産生され7), また, 刺激後 2 分以内に細胞表面に GMP-140 が発現する7). そ の後, 対照群との差は急速に小さくなるが, 20 分 後においても明らかな発現量の差が認められる (data not shown)。血管内皮細胞の PAF 産生と GMP-140 の発現がきわめて似た経時変化を辿る ことから, Prescott らは, 血管内皮細胞への顆粒 球接着には，血管内皮細胞が産生する PAF と血 管内皮細胞上に発現する GMP-140 がたがいに密 接に関わると考えているが5,9), GMP-140 の発現 に直接 PAF が関わるかどうかについて明確にさ 
れていない.

ヒスタミンあるいはトロンビンを添加して 20 分後の, 培養血管内皮細胞の GMP-140 発現に対 する PAF 拮抗薬の作用を検討した今回の結果か らも，ヒスタミンあるいはトロンビン刺激で産生 される PAF は, GMP-140 の発現に対して影響 を与えていないことが示唆された。したがって， 好中球の血管内皮細胞認識のプロセスの中で確か に PAF は関わってるいるものの，その作用は少 なくとも接着分子である ICAM-1, ELAM-1 あ るいは GMP-140 などの量的変化および質的変化 に影響を与えた結果ではないことが示唆された。

また， GMP-140 が血管内皮細胞上で PAF と ともに存在することが好中球接着や遊走に必要で あるならば, 抗 GMP-140 抗体は PAF 拮抗薬と 同様に，好中球の血管内皮細胞への接着や内皮細 胞層を介する遊走を抑制するはずである.しかし， 抗 GMP-140 抗体はヒスタミンやトロンビンによ る好中球の接着をまったく抑制しなかった(図 6 ). したがって, PAF 拮抗薬による好中球の接 着および遊走の抑制作用機序に，GMP-140 の発 現誘導は関係していないことが示唆された.なお， 接着分子抗体による解析では, Fcレセプターを介 する接着元進を同時に測定する可能性を除くた め, 現在, 接着分子抗体の $\mathrm{Fa}, \mathrm{b}$ フラグメントを 調製して検討を行っている.

また，トランスウェルを用いた実験系において も抗 GMP-140 抗体はまったく抑制を示さず，一 方, 抗 LFA-1 抗体では遊走がほとんど抑制され (図 6 ), ICAM-1 と LFA-1 経路による細胞接着 の重要性が示唆された。

ラットのアレルギー性炎症モデルにおいて, PAF 拮抗薬は好中球の炎症局所への浸潤を抑制 するが，その作用機序は血管内皮細胞表面におけ る GMP-140, ICAM-1 あるいは ELAM-1 など の接着分子の発現誘導や接着能を抑制するためで はないことが示唆された. PAF 拮抗薬は, 血管内 皮細胞が産生する PAF に拮抗して，これらの接
着分子とは別の経路による好中球接着を抑制した ためであることも考えられ，今後さらに解析する 必要がある。

\section{文 献}

1) Tsurufuji, S., Yoshino, S., Ohuchi, K. : Induction of allergic air-pouch inflammation in rats. Int. Archs. Allergy Appl. Immunol. 68:326-331, 1982.

2) Ohuchi, K., Hirasawa, N., Watanabe, M., Tsurufuji, S. : Pharmacological analysis of the vascular permeability response in the anaphylactic phase of allergic inflammation in rats. Eur. J. Pharmacol. $117: 337-345,1985$.

3) Watanabe, M., Sugidachi, A., Omata, M., Hirasawa, N., Mue, S., Tsurufuji, S., Ohuchi, K. : Possible role for platelet-activating factor in neutrophil infiltration in allergic inflammation in rats. Int. Archs. Allergy Appl. Immunol. 92 : 396-403, 1990.

4) Watanabe, M., Arakida, Y., Tanabe, J., Sugidachi, A., Hirasawa, N., Mue. S., Ohuchi, K.: Pharmacological analysis of neutrophil chemotactic factor production by leucocytes and roles of PAF in allergic inflammation in rats. Br. J. Pharmacol. 111: 123-130, 1994.

5) Zimmerman, G. A., McIntyer, T. M., Mehra, M., Prescott, S. M. : Endothelial cell-associated platelet-activating factor: A novel mechanism for signaling intercellular adhesion. J. Cell Biol. 110 : 529-540, 1990.

6) Watanabe, M., Yagi M., Omata, M., Hirasawa, N., Mue, S., Tsurufuji, S., Ohuchi, K. : Stimulation of neutrophil adherence to vascular endothelial cells by histamine and thrombin and its inhibition by PAF antagonists and dexamethasone. Br. J. Pharmacol. 102 : 239-245, 1991.

7) Prescott, S. M., Zimmerman, G. A., McIntyer, T. M. : Platelet-activating factor. J. Biol. Chem. 29 : 17381-17384, 1990

8) Hattori, R., Hamilton, K. K., Fugate, R. D., McEver, R. P., Sims, P. J. : Stimulated secretion of endothelial von Willebrand factor is accompanied by rapid redistribution to the cell surface of the intracellular granule membrane protein GMP-140. J. Biol. Chem. 264 : 7768-7771, 1989.

9) McEver, R. P. : Leukocyte interactions mediated by GMP-140. Cellular and Molecular Mechanisms of Inflammation. Vascular Adhesion Molecules. (ed. Cochrane, C. G., Gimbrone, Jr., M. A.), Academic Press, 1991, p 15-29. 